\title{
DISCOVERING WHAT MAKES A SME WEBSITE GOOD FOR INTERNATIONAL TRADE
}

\author{
Engin AKMAN $^{1^{*}}$, Metin DAGDEVIREN $^{2}$ \\ ${ }^{1}$ Department of International Trade, Cankiri Karatekin University, Uluyazi, 18000 Cankiri, Turkey \\ ${ }^{2}$ Department of Industrial Engineering, Gazi University, 06570 Maltepe, Ankara, Turkey
}

Received 10 October 2015; accepted 26 November 2016

\begin{abstract}
The effectiveness of websites has an impact on the representation of a SME and can have an effect on foreign trade. Thus, developing a reliable and robust model to assess the effectiveness of SME websites is important for researchers and practitioners. The aim of the study is to propose a SME website efficiency evaluation methodology from an international trade perspective. Determining the effectiveness of websites is a multi-dimensional decision-making problem which encompasses the assessment of information quality, system quality, and service quality. The criteria and sub-criteria affecting website effectiveness were determined through literature research and expert panel assistance. AHP method was utilized to determine the relative weights of the evaluation criteria in the study. Then, fuzzy linguistic variables were adopted to rank the websites of SMEs engaged in foreign trade. The proposed evaluation model identifies key factors regarding the criteria and sub-criteria of a website effectiveness. The model can provide a helpful reference in designing useful websites which are an important task for SMEs involved in international trade.
\end{abstract}

Keywords: SME websites, international trade, website evaluation, multi-criteria decision-making, analysis, fuzzy linguistic scale, AHP.

JEL Classification: C63, F10, L21, M21.

\section{Introduction}

Competing in an international environment, promoting the goods and services of a company, reaching more clients globally to make more revenues and building a more sustainable concern require a significant amount of funds and experience. Many of the SMEs experience difficulties in attaining benefits of foreign trade as they lack necessary resources such as capital and skills. Presentation of a company and the goods or services offered is crucial for access to foreign markets. Improved access to international markets and promotion of products in foreign markets encourage the firms to export and increase the success in new markets (Lileeva, Trefler 2010; Akman 2016). Katsikeas et al. (1997) show that export market

*Corresponding author. E-mail: akmanakman@yahoo.com 
accessibility is a more significant factor in export success among SMEs compared to larger firms. Entrance to new markets is facilitated only by communication between the trading parties which incurs additional costs. Fink et al. (2005) attested that communication costs have a significant impact on international trade and the decrease in communication costs are one of the causes of World trade growth. The internet offers fast, borderless and cheaper opportunities for representing products and services. This advantage lowers barriers to access international markets for SMEs. Contractor et al. (2005) further argued that the usage of internet by corporations alleviates inadequacies in international business experience. The internet is considered as a common marketing ground for trading companies. It can serve as a medium to overcome disadvantages of SMEs in promoting their products in foreign markets. International networking is one of the determining factors of export success. The websites, official representatives of corporations, are likely to have a central function in international networking of a company (Glavas, Mathews 2014). Nearly 50\% of the SMEs consider official websites as a facilitator of network building (Madill, Neilson 2010). However, the effectiveness of websites and the success of their presentation of the products or offers are key elements in achieving this function.

The invention of the internet has changed many aspects of life by lowering limitations to access of information and the ease of communication on the World Wide Web. The effects of this change have been obvious in business and international trade. The rapid spread of internet lowered the barriers to international trade and significantly expanded the export volume of the World (Freund, Weinhold 2004). Export information availability, international network building, and marketing through websites facilitate exports and gradually increase the export market shares of a corporation (Bianchi, Mathews 2016). Utilizing websites to provide better communication functions increase exporters' performance in foreign markets (Wang et al. 2011). Usage of internet and websites as a marketing tool contributes to the internationalization and export success of SMEs in both production and service industries (Mathews et al. 2012; Moini, Tesar 2005; Choi 2010). On the other hand, the existing customers also demand an effective website. The influence of the current customers' pressure on the adoption and effectiveness of a website is higher than other factors such as competitor pressure or the motivation of reaching new customers (Beckinsale et al. 2006). Goedhuys and Sleuwaegen (2009) indicate that the SMEs actively interacting with their clients through their websites achieve higher market share and growth rates than their counterparts. Therefore, designing an effective website is not only a catalyst for engaging in foreign markets and increasing their sales but also an important concern for sustaining SMEs in today's business atmosphere. The empirical studies show that the SMEs are deriving benefits from the use of websites. This trend enabled the SMEs in both emerging and developed countries initiate trade beyond their local borders in the past decade.

The Internet as a virtual platform is an advantage for SMEs with no or lower international networks and helps them in engaging in foreign trade. However, ineffective websites are likely to turn this advantage into a disadvantage. Website effectiveness is one of the important aspects of international networking and thus, international trade for SMEs. Website effectiveness in different fields has been studied extensively in the literature. However, the problem of website effectiveness of SMEs in the realms of foreign trade is an issue that hasn't been 
addressed adequately. We were motivated by the lack of studies focusing on the evaluation of website effectiveness of SMEs from the perspective of the users in international trade. The focus of our research is a distinguishing feature and thus, the study makes a significant contribution to the body of literature. The proposed model utilizes multi-criteria decisionmaking models (MCDM) for evaluating and ranking the effectiveness of SME websites. The results of the research can help SMEs engaged in foreign trade to assess their website effectiveness and develop policies for website enhancement. The findings of the study have a potential to form a basis for further studies on the relation of website efficiency and export performance of SMEs.

AHP is one of the most useful and popular methodologies in multi-criteria decisionmaking problems (Mardani et al. 2015). An MCDM; Analytic Hierarchy Process (AHP) is utilized to evaluate SME websites in this study. The nature of the website evaluation criteria is qualitative with sometimes conflicting assessments of experts. AHP enables to combine a group consensus by weighing the criteria and sub-criteria to select the best suitable criteria (Akincilar, Dagdeviren 2014). The number of respondents, all foreign trade experts, to our questionnaire is forty-nine. Therefore, we consider AHP is an ideal method for the study.

The studies of Ho (2008), Zavadskas and Turskis (2011), Akkaya et al. (2015), Tyagi (2016) and Veisi et al. (2016) show that AHP is an MCDM tool that has been used in many areas ranging from economics, education, commerce, manufacturing and politics to finance, engineering, military, environment and agriculture. Akincilar and Dagdeviren (2014), Lee and Kozar (2006), Lin (2010), Chen et al. (2012) and Yu et al. (2011) are some website evaluation studies employing AHP method.

This paper is divided into five sections. After describing the problem in this section, a literature review on website evaluation followed. The second section is dedicated to introducing AHP methodology. The empirical analysis, results, and discussion are presented in the third section. Conclusions and future research take part in the last Section.

\section{Literature review}

Participants of international trade generally start with a preliminary research usually carried on the internet in this day. Thus, official websites are not only an information source for current customers but also another path for gaining new customers. Websites are open exhibitions with no access limitations of time, location, and borders. Effective websites are likely to produce more successful results in exploiting the opportunities of the internet. Samiee (1998), one of the earlier studies on the role of websites on the export performance, puts forth that having a corporate website does not present a comparative advantage in export markets over competitors. Actually, making better use of the opportunities websites offer and increasing website effectiveness through skills and experience does provide higher competitive power in export markets. Assessing the enterprise's own website and the websites of competitors' websites are important in promoting the competitiveness level and achieving competitive advantage (Li 2015). The design and function of the website of an organization is an important factor in communicating with customers. Unfortunately, many corporations, particularly SMEs, fail to realize the importance of online presence and its impact on the 
customers (Cheek et al. 2016). Sinkovics and Penz (2006) indicate that consumers as decision makers value the content and design of websites serving their essential objectives. Corporations need to develop methodologies, procedures, and practices to achieve this goal.

The business professionals and researchers are focused on website evaluation and success factors to support the overall improvement of websites. Some of the recent examples of the studies are given as follows: the evaluation of C2C e-commerce websites (Li 2015; Masudin, Sapturo 2016), the evaluation of group-buying websites (Chen et al. 2012), library websites (Xiaolan et al. 2013), hotel websites (Ting et al. 2013; Akincilar, Dagdeviren 2014), bank websites (Waite et al. 2011; Kaya, Kahraman 2011; Ecer 2014), trading websites (Meng, Wu 2014), SME websites (Sanders, Galloway 2013; Karmokar, Singh 2012; Sinkovics, Penz 2006; Stockdale et al. 2005; Houghton, Winklhofer 2004), corporate websites for export marketing (Dou, Tan 2002), B2C e-business websites (Kang et al. 2016; Lee, Kozar 2006; Yu et al. 2011), course websites (Lin 2010) and business school websites (Kincl, Štrach 2012).

Sinkovics and Penz (2006) conducted a research using Likert scale questionnaire to assess the factors impacting on SME website empowerment. They suggested five dimensions with the assistance of experts panel; general aspects, information, transaction, relationship and target audience. Their findings indicate interactivity and information are the most important aspects of website effectiveness. Stockdale et al. (2005) analyzed the effectiveness of SME business to business websites from a user perspective. They assessed the websites using eQual 4.0 evaluation instrument and concluded that SMEs need to improve information and service efficiency dimensions of their websites. Lee and Kozar (2006) researched the criteria affecting website effectiveness, and the relationship between business performance and website preference adopting AHP methodology. They stated system quality and navigability are considered the most important attributes and demonstrated that there is a significant relationship between financial performance and website preference. Sanders and Galloway (2013) evaluated the websites of rural small firms using Web Assessment Index (WAI). They concluded that the effectiveness of small firms' websites is generally lower than that of large firms. The quality of rural SMEs websites differs with the location of the company. SMEs need to increase website effectiveness given their remoteness and contribution on rural economies.

Dou and Tan (2002) investigated the impact of websites on export marketing and tested the proposed hypothesis utilizing ANOVA model. They suggested that trustworthiness, comprehensive product information, multiple languages, customization capability, and responsiveness are critical components of an exporter's website. It is concluded that the companies in different industries need to strengthen transaction or communication capabilities of the websites.

Cebi (2013) investigated criteria affecting website effectiveness and their alteration with the website type. MCDM methods like Delphi, DEMATEL and TOPSIS were employed for empirical analysis. Usability, visual aspects, technical adequacy, content, security, communication, and prestige were considered as main design parameters. It is concluded that significance of the criteria shows different patterns for different types of websites (commercial, information, entertainment, communication). Kincl and Štrach (2012), attempted to compare and contrast user satisfaction attributes to find out practical measurement tools for business school website evaluation. Their research model evaluated content, presentation (colour, ap- 
peal, layout, navigation) and overall impression as success criteria, identifying a decision-tree analysis with the results of a Likert scale questionnaire. The results indicate that content and navigation are critical factors for website effectiveness.

Ecer (2014) proposed a hybrid evaluation model to assess the effectiveness of banking websites combining AHP and COPRAS-G methods. The study determined the weights of the criteria by AHP method and COPRAS-G method is used to rank the websites for their effectiveness. Ecer (2014) adopted three main criteria (information quality, service quality, and system quality) and ten sub-criteria. He concluded that most important criterion is information quality. Reliability, navigability and response time are significant sub-criteria. The study also ranked 17 banking websites utilizing COPRAS-G methodology.

Bulicek and Drdla (2015) evaluated quality of urban public transport websites utilizing AHP method. The research was intended to guide transport companies in fulfilling quality standards of information service provided by websites. Travel information, system information, additional system information and information for non-travel purposes have been described as criteria as well as 35 sub-criteria. The weights of 35 sub-criteria have been calculated by using AHP method. The quality of transport websites of 161 cities were ranked by estimated weights of individual information elements.

Kang et al. (2016) assessed e-commerce websites using fuzzy hierarchical TOPSIS based on E-S-QUAL. The researchers defined four criteria such as efficiency, fulfilment, system availability, and privacy and 22 sub-criteria for determining the service quality of websites. The hierarchical structure has been constructed using TOPSIS and the weights of the criteria have been decided by E-S-QUAL. The weights of the criteria show that fulfilment, efficiency, privacy and system availability are important for a B2C website respectively. The ranking of the preferences for the six selected B2C e-commerce websites has been carried out utilizing linguistic values and fuzzy numbers.

There are specific elements contributing to the quality and efficiency of a website. These criteria are considered as proxies of an efficient website in the relevant literature. We reviewed them with the help of the experts' panel and added some criteria to measure the contribution of websites to the export performance of a company. The criteria, sub-criteria, and several studies employed them are given in Table 1.

Table 1. The criteria and sub-criteria of website effectiveness

\begin{tabular}{|l|l|l|}
\hline \multicolumn{1}{|c|}{ Criteria } & \multicolumn{1}{|c|}{ Definition } & \multicolumn{1}{|c|}{ Studies } \\
\hline \multicolumn{2}{|l|}{ Information Quality (IQ) } \\
\hline $\begin{array}{l}\text { Product Information } \\
\text { (PrI) }\end{array}$ & $\begin{array}{l}\text { Clear explanation of what the } \\
\text { company offers and product } \\
\text { details }\end{array}$ & $\begin{array}{l}\text { Dou and Tan (2002), Expert panel's } \\
\text { proposal Fettah }\end{array}$ \\
\hline $\begin{array}{l}\text { Company } \\
\text { Information (CoI) }\end{array}$ & $\begin{array}{l}\text { Information about the company, } \\
\text { representation of the company, } \\
\text { location, facilities etc. }\end{array}$ & Expert panel's proposal \\
\hline Currency (Cur) & $\begin{array}{l}\text { Up-to-dateness of the content, } \\
\text { reflecting the current state }\end{array}$ & $\begin{array}{l}\text { Lee and Kozar (2006), Chou and Cheng } \\
\text { (2012), Cebi (2013), Ecer (2014) }\end{array}$ \\
\hline
\end{tabular}


End of Table 1

\begin{tabular}{|c|c|c|}
\hline Criteria & Definition & Studies \\
\hline $\begin{array}{l}\text { Export orientation } \\
(\mathrm{ExO})\end{array}$ & $\begin{array}{l}\text { Information about export } \\
\text { activities, distributors, } \\
\text { certificates, exhibitions etc. }\end{array}$ & Expert panel's proposal \\
\hline \multicolumn{3}{|l|}{ System Quality (SyQ) } \\
\hline Navigability (Nav) & $\begin{array}{l}\text { Ease of navigation within the } \\
\text { website, obtaining necessary } \\
\text { information }\end{array}$ & $\begin{array}{l}\text { Lee and Kozar (2006), Lin (2010), Chen } \\
\text { et al. (2012), Ting et al. (2013), Kincl and } \\
\text { Štrach (2012), Chou and Cheng (2012), } \\
\text { Cebi (2013), Ecer (2014) }\end{array}$ \\
\hline Accessibility (Acc) & $\begin{array}{l}\text { Ability to access the website and } \\
\text { its links }\end{array}$ & $\begin{array}{l}\text { Lin (2010), Chou and Cheng (2012), } \\
\text { Akincilar and Dagdeviren (2014), Cebi } \\
\text { (2013), Ecer (2014) }\end{array}$ \\
\hline Attractiveness (Att) & $\begin{array}{l}\text { Visual attractiveness of design, } \\
\text { layout, and presentation of } \\
\text { information }\end{array}$ & $\begin{array}{l}\text { Lin (2010), Karmokar and Singh } \\
\text { (2012), Yu et al. (2011), Kincl and } \\
\text { Strach (2012), Akincilar and Dagdeviren } \\
\text { (2014), Cebi (2013) }\end{array}$ \\
\hline \multicolumn{3}{|l|}{ Service Quality (SeQ) } \\
\hline Security (Sec) & $\begin{array}{l}\text { Privacy rights of users are } \\
\text { protected, security policies are } \\
\text { clearly stated }\end{array}$ & $\begin{array}{l}\text { Sinkovics and Penz (2006), Chen et al. } \\
\text { (2012), Yu et al. (2011), Chou and Cheng } \\
\text { (2012), Akincilar and Dagdeviren (2014) }\end{array}$ \\
\hline Reliability (Rel) & $\begin{array}{l}\text { Reliable, accurate and consistent } \\
\text { contents }\end{array}$ & $\begin{array}{l}\text { Yu et al. (2011), Chou and Cheng (2012), } \\
\text { Akincilar and Dagdeviren (2014), Ecer } \\
\text { (2014) }\end{array}$ \\
\hline Responsiveness (Res) & $\begin{array}{l}\text { Interactivity of website, } \\
\text { communicating with visitors and } \\
\text { providing help if necessary }\end{array}$ & $\begin{array}{l}\text { Lee and Kozar (2006), Chen et al. (2012), } \\
\text { Ting et al. (2013), Chou and Cheng } \\
\text { (2012), Akincilar and Dagdeviren (2014), } \\
\text { Cebi (2013) }\end{array}$ \\
\hline
\end{tabular}

\section{The AHP methods}

AHP, developed by Saaty (1980), addresses how to determine the relative importance of a set of activities in an MCDM problem. AHP combines subjective assessments based on qualitative criteria and objective assessments based on quantitative criteria analytically (Saaty et al. 2015). The construction of the method is based on three principles: structure of the model; comparative evaluation of the substitutes and the criteria; synthesis of the priorities. AHP has been widely used in solving many complicated decision-making problems in the literature (Dagdeviren, Yuksel 2008; Fox 2015; Franco 2014; Mosadeghi et al. 2015).

In the first step, a complex decision problem is structured as a hierarchy. AHP initially breaks down a complex multi-criteria decision-making problem into a hierarchy of interrelated decision elements (criteria, decision alternatives). With the AHP, the objectives, criteria, and alternatives are arranged in a hierarchical structure similar to a family tree. A hierarchy has at least three levels: overall goal of the problem at the top, multiple criteria that define alternatives in the middle, and decision alternatives at the end (Albayrak, Erensal 2004). 
The second step is the comparison of the alternatives and the criteria. Once the problem has been decomposed and the hierarchy is constructed, prioritization procedure starts in order to determine the relative importance of the criteria within each level. The pairwise judgment starts from the second level and finishes in the lowest level, alternatives. In each level, the criteria are compared pairwise according to their levels of influence and based on the specified criteria in the higher level (Albayrak, Erensal 2004). In AHP, multiple pairwise comparisons are based on a standardized comparison scale of nine levels (Table 2).

Table 2. Nine-point intensity of importance scale and its description

\begin{tabular}{|l|c|}
\hline \multicolumn{1}{|c|}{ Definition } & Intensity of importance \\
\hline Equally important & 1 \\
\hline Moderately more important & 3 \\
\hline Strongly more important & 5 \\
\hline Very strongly more important & 7 \\
\hline Extremely more important & 9 \\
\hline Intermediate values & $2,4,6,8$ \\
\hline
\end{tabular}

Let $C=\left\{C_{j} \mid j=1,2, \ldots, n\right\}$ be the set of criteria. The result of the pairwise comparison on $n$ criteria can be summarized in an $(n \times n)$ evaluation matrix A in which every element $a_{i j}$ $(i, j=1,2, \ldots, n)$ is the quotient of weights of the criteria, as shown in Eq. (1):

$$
A=\left[\begin{array}{cccc}
a_{11} & a_{12} & \ldots & a_{1 n} \\
a_{21} & a_{22} & \ldots & a_{2 n} \\
\vdots & \vdots & \ddots & \vdots \\
a_{n 1} & a_{n 2} & \ldots & a_{n n}
\end{array}\right], a_{i i}=1, a_{j i}=1 / a_{i j}, a_{i j} \neq 0 .
$$

At the last step, the mathematical process commences to normalize and find the relative weights for each matrix. The relative weights are given by the right eigenvector $(w)$ corresponding to the largest eigenvalue $\left(\lambda_{\max }\right)$, as

$$
A w=\lambda_{\max } w .
$$

If the pairwise comparisons are completely consistent, the matrix $A$ has rank 1 and $\lambda_{\max }=n$. In this case, weights can be obtained by normalizing any of the rows or columns of the matrix (Li, Liu 2015).

It should be noted that the quality of the output of the AHP is strictly related to the consistency of the pairwise comparison judgments. The consistency is defined by the relation between the entries of $A: a_{i j} \times a_{j k}=a_{i k}$. The consistency index (CI) is:

$$
\mathrm{CI}=\left(\lambda_{\max }-n\right) /(n-1) .
$$

The final consistency ratio (CR), usage of which let someone to conclude whether the evaluations are sufficiently consistent, is calculated as the ratio of the $\mathrm{CI}$ and the random index (RI), as indicated in Eq. (4):

$$
\mathrm{CR}=\mathrm{CI} / \mathrm{RI}
$$


The number 0.1 is the accepted upper limit for CR. If the final consistency ratio exceeds this value, the evaluation procedure has to be repeated to improve consistency. The measurement of consistency can be used to evaluate the consistency of decision-makers as well as the consistency of overall hierarchy.

\section{Empirical analysis}

Our model is developed in four phases; structuring the goal, determination of criteria, weighing and ranking the criteria by means of AHP, calculation of precedence of the websites. Our goal is evaluation of SME websites and their effectiveness from the foreign trade aspect.

\subsection{Determination of criteria and sub-criteria}

Determining the criteria is critical for any decision-making problem. Previous studies on website evaluation are considered at this stage. The scarcity of the studies on the impact of website effectiveness on foreign trade success has led us consulting professionals. An experts' panel including academics and foreign trade managers is constructed to assess the criteria contributing the efficiency of websites. The experts' panel included two academics and five senior export managers with more than 15 years of experience in export trading. Two academics are the authors of this article; one of them has considerable experience in foreign trade prior to his full-time researcher job. The other author has significant expertise in multi-criteria decision making models and author of numerous articles in this field. Senior export managers have been chosen from different industries to reflect the views of experts from different fields. The members of experts' panel are from the sectors of iron and steel, textile, medical equipment, furniture and plastic household goods. The criteria, determined by literature review have been assessed by the experts' panel. This assessment has been conducted with the help of a preliminary questionnaire designed as 5-point Likert scales. We calculated the averages for each criterion based on the individual evaluation of experts and determined the criteria to be employed in the study. The sub-criteria about system quality and service quality employed in the study (seen in Table 1) were largely respected sufficient as these criteria are common in evaluating any websites.

However, information quality and the messages conveyed to the end-users via website have been considered as a distinguishing aspect of an exporter's website. Thus, export orientation of the company (i.e. exhibitions, certificates, foreign representatives etc.) reflected in the website was suggested as effective criteria by the expert panel. Detailed product and company information were also included as success criteria with the proposal of the expert panel. As far as we are concerned, export orientation hasn't been considered as an evaluation criteria in the previous studies. Although about $95 \%$ of the SMEs utilize their websites for information provision for their clients (Madill, Neilson 2010), company and product information haven't been assessed in previous website evaluation studies. Only Dou and Tan (2002) included product information in their website evaluation research. The sub-criteria pertaining to the information quality are among distinctive features of our study compared to other website evaluation studies. The parameters contributing to designing an efficient 
website for an exporter company are presented in Table 1. The hierarchy of the model is configured based on the adopted 3 criteria and 10 sub-criteria.

\subsection{Weighing the criteria}

Weighing and ranking of the criteria and sub-criteria are performed utilizing the AHP which is an effective tool for the evaluation of qualitative criteria. The weights of the criteria were obtained with a unique questionnaire in the AHP method. The questionnaire allowing the decision makers to compare each pair of criteria based on their own knowledge and experience was constructed. The respondents evaluated the relative importance of each criterion comparing it with the competing criteria on the other side. Traditional format for AHP questionnaire has a nine-point scale. The description of this scale is demonstrated in Table 2. The comparisons, performed by personal judgments and the expertise of the participants, are critical in producing reliable results. Therefore, we sent the questionnaires to the target group made up of members who have 11,3 years of experience on average in foreign trade. The target group has been chosen from the employees of SMEs (with less than 10 million USD turnover and 150 employees) who are engaged in export business and willing to contribute our research. The respondents are working at the export departments of the SMEs or in the case of not having such a specific department; they are the employees who perform export activities of the company. They are representatives of their companies in terms of their foreign marketing and sales.

The assistance of local Chamber of Industry and Development Agency enabled us to access and recruit the target group. Every respondent was contacted via telephone or e-mail and explained the aim and the structure of the questionnaire to increase consistency and transparency. In total, 49 experts contributed to our research completing the questionnaires. The weights are calculated by the geometric mean of the values as this is a group decision-making procedure. Table 3 exhibits pair-comparison matrix and weights of criteria. Table 4 exhibits local and global weights of sub-criteria obtained by AHP method. Global weights of sub-criteria are calculated by multiplying weight of hierarchical criteria with the local weight of sub-criteria.

The comparisons are carried out via subjective personal judgments and naturally, inconsistency might be faced. Therefore, consistency confirmation is carried out to evaluate the degree of consistency between the pairwise comparisons. It is confirmed that consistency ratio is below the critical value of 0.1 at all levels ( $\mathrm{CR}$ of criteria $=0.04$; CR of IQ subcriteria $=0.05$; CR of SyQ sub-criteria $=0.04$; CR of SeQ sub-criteria $=0.10$ ). Therefore, the results are robust.

Table 3. Pair-comparison matrix and weights of criteria

\begin{tabular}{|l|c|c|c|c|}
\hline \multicolumn{1}{|c|}{ Criteria } & $\begin{array}{c}\text { Information } \\
\text { Quality (IQ) }\end{array}$ & $\begin{array}{c}\text { System Quality } \\
(\text { SyQ })\end{array}$ & $\begin{array}{c}\text { Service Quality } \\
(\mathrm{SeQ})\end{array}$ & Weights \\
\hline Information Quality (IQ) & 1 & 1.94 & 1.51 & 0.461 \\
\hline System Quality (SyQ) & 0.52 & 1 & 1.14 & 0.270 \\
\hline Service Quality (SeQ) & 0.66 & 0.88 & 1 & 0.269 \\
\hline
\end{tabular}


Table 4. Local and global weights of sub-criteria

\begin{tabular}{|c|l|c|c|}
\hline Criteria & \multicolumn{1}{|c|}{ Sub-Criteria } & Local Weights & Global Weights \\
\hline \multirow{4}{*}{ IQ } & Product Information & 0.355 & 0.164 \\
\cline { 2 - 4 } & Company Information & 0.181 & 0.083 \\
\cline { 2 - 4 } & Export Orientation & 0.106 & 0.049 \\
\cline { 2 - 4 } & Currency & 0,358 & 0,165 \\
\hline \multirow{4}{*}{ SyQ } & Navigability & 0.453 & 0.122 \\
\cline { 2 - 4 } & Accessibility & 0.413 & 0.112 \\
\cline { 2 - 4 } & Attractiveness & 0.134 & 0.036 \\
\hline \multirow{3}{*}{ SeQ } & Security & 0.350 & 0.094 \\
\cline { 2 - 4 } & Reliability & 0.440 & 0.118 \\
\cline { 2 - 4 } & Responsiveness & 0.209 & 0.056 \\
\hline
\end{tabular}

\subsection{Ranking of the websites}

The websites of three SMEs operating in household plastics sector were chosen for assessment. It was attempted to show if any of the companies possess more advantage in gaining clients via their websites. It is possible to rank the websites for their efficiency using reliable weights of criteria obtained by AHP methodology. Alternative websites are ranked in the frames of the sub-criteria by experts' panel. The experts' panel consisting of seven members who contributed to the selection of the criteria (section 3.1) has performed the ranking of the websites. In the ranking phase, the panel selected the determined linguistic values given in Table 5 for their assessment of each criteria for a particular website. Then, the expressions are converted into scale values to be used in the calculations. The scale values are obtained using fuzzy numbers as developed by Cheng et al. (1999). The panel examined the websites and expressed their personal judgments for each of the sub-criteria verbally as very good, good, fair, poor and very poor. Then, the panel reached a consensus on each criteria suggesting the group opinion as one of the five verbal expressions stated above. In order to utilize verbal opinions of experts in the ranking, transformation of them to numerical values is needed. The approach of Cheng et al. (1999) is adopted at this stage. They proposed a model to translate verbal linguistic values expressing opinions into the mean of fuzzy numbers. The expert opinions expressed in linguistic values are translated into the scale values exhibited in Table 5 and used to measure the sub-criteria for the website of each company.

Table 5. Linguistic values and scale values

\begin{tabular}{|l|c|c|}
\hline \multicolumn{1}{|c|}{ Linguistic value } & Fuzzy numbers & Scale value \\
\hline Very good $(\mathrm{VG})$ & $(0.75,1.00,1.00)$ & 1 \\
\hline Good $(\mathrm{G})$ & $(0.50,0.75,1.00)$ & 0.75 \\
\hline Fair $(\mathrm{F})$ & $(0.25,0.50,0.75)$ & 0.50 \\
\hline Poor $(\mathrm{P})$ & $(0,0.25,0.50)$ & 0.25 \\
\hline Very poor $(\mathrm{VP})$ & $(0,0,0.25)$ & 0 \\
\hline
\end{tabular}


Table 6. Ranking of alternative websites

\begin{tabular}{|c|c|c|c|c|c|c|c|c|c|c|}
\hline \multirow[b]{2}{*}{ Sub-criteria } & \multirow[b]{2}{*}{$\begin{array}{l}\text { Global } \\
\text { Weights }\end{array}$} & \multicolumn{3}{|c|}{ Company 1} & \multicolumn{3}{|c|}{ Company 2} & \multicolumn{3}{|c|}{ Company 3} \\
\hline & & 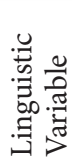 & 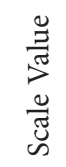 & $\begin{array}{l}3 \\
0 \\
0 \\
\vdots \\
\vdots \\
0\end{array}$ & 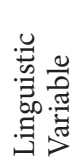 & 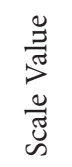 & $\begin{array}{l}3 \\
0 \\
0 \\
\vdots \\
\vdots \\
0\end{array}$ & 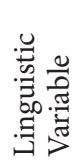 & 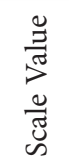 & 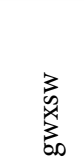 \\
\hline $\begin{array}{l}\text { Product } \\
\text { Information }\end{array}$ & 0.164 & VG & 1 & 0.164 & G & 0.75 & 0.123 & VG & 1 & 0.164 \\
\hline $\begin{array}{l}\text { Company } \\
\text { Information }\end{array}$ & 0.083 & G & 0.75 & 0.063 & $\mathrm{P}$ & 0.25 & 0.021 & G & 0.75 & 0.062 \\
\hline $\begin{array}{l}\text { Export } \\
\text { Orientation }\end{array}$ & 0.049 & $\mathrm{P}$ & 0.25 & 0.012 & $\mathrm{P}$ & 0.25 & 0.012 & VP & 0 & 0.000 \\
\hline Currency & 0.165 & $\mathrm{~F}$ & 0.5 & 0.083 & $\mathrm{~F}$ & 0.5 & 0.083 & $\mathrm{P}$ & 0.25 & 0.041 \\
\hline Navigability & 0.122 & G & 0.75 & 0.092 & $\mathrm{P}$ & 0.25 & 0.031 & $\mathrm{~F}$ & 0.5 & 0.061 \\
\hline Accessibility & 0.112 & G & 0.75 & 0.084 & $\mathrm{~F}$ & 0.5 & 0.056 & G & 0.75 & 0.084 \\
\hline Attractiveness & 0.036 & $\mathrm{~F}$ & 0.5 & 0.018 & $\mathrm{~F}$ & 0.5 & 0.018 & VP & 0 & 0.000 \\
\hline Security & 0.094 & $\mathrm{~F}$ & 0.5 & 0.047 & $\mathrm{~F}$ & 0.5 & 0.047 & $\mathrm{~F}$ & 0.5 & 0.047 \\
\hline Reliability & 0.118 & G & 0.75 & 0.089 & $\mathrm{P}$ & 0.25 & 0.030 & $\mathrm{~F}$ & 0.5 & 0.059 \\
\hline Responsiveness & 0.056 & G & 0.75 & 0.042 & G & 0.75 & 0.042 & $\mathrm{P}$ & 0.25 & 0.014 \\
\hline Total & & & & 0.692 & & & 0.462 & & & 0.533 \\
\hline
\end{tabular}

The preference ranking of the websites is determined by using global weight values (Table 4) and the linguistic measurement scale (Table 5). The calculations are given in Table 6. The results show that preference rankings of the websites are as follows: Company 1, Company 3 and Company 2. The ranking indicates that the interested parties will probably favour website of Company 1 over others. This advantage can help Company 1 to increase prospects of turning visitors into clients and satisfy existing ones. Another implication of the ranking is that company 2 and 3 should take a closer look at the website of company 1 as a benchmark and get ideas for how to improve their website.

\subsection{Discussion}

Samiee (1998) argues that communicating with target customers successfully is the key factor for website effectiveness. Effective use and capabilities of websites have a facilitating role in increasing the exports of SMEs (Hajidimitriou, Azaria 2009). Websites play this role through lowering the effects of distance between the parties and providing a medium for constructing an export network. Sinkovics and Penz (2006) assert that SME websites need to be empowered in order to gain benefits of websites. There are many website evaluation studies which contribute to this empowerment efforts in the established literature. However, evaluation of SME websites from the view of international trade is an issue not addressed sufficiently and our results can have important implications. 
Many SMEs adopt and sustain websites as they regard websites as a tool for accessing new markets and expanding their export sales. Therefore, SMEs allocate funds and bear costs of websites expecting to get profits of them. The key problem we dealt in our empirical analysis is the impact of websites on the export potential of SMEs. Our aforementioned results portray the views of export specialists and have a potential to provide a proper approach for SME website building. More significant sub-criteria need to be drawn more attention if the corporations plan to increase the flow of foreign customers based on their websites.

The global weights of the criteria, shown in Table 4, range from 0.036 (attractiveness) to 0.165 (currency). The ranking of the criteria depicts the hierarchical importance which can guide professionals and researchers in evaluating SME websites. Findings of the study indicate that information quality $(0.461)$ is the most important factor affecting SME website quality. This is consistent with Lin (2010) and provides further evidence for Sinkovics and Penz (2006) who put forth that the websites serving the visitors' primary objectives increase end-user satisfaction and motivation to use websites as an information basis. The primary objective within the international trade scope is obtaining accurate information to be able to establish reliable connections globally. The experts value system quality (0.270) and service quality (0.269) as equally important factors in terms of website efficiency. The weights of criteria support the results of Ecer (2014) who evaluated banking websites: information quality (0.539), service quality (0.163) and system quality (0.298). The analytic results show that; currency and product information are the most critical and almost equal factors when global weights of sub-criteria are considered. Foreign trade experts prioritize "current" and "detailed" product information in gaining new customers via websites.

Navigability, reliability, and accessibility are among the other critical factors as illustrated in Table 4. Interestingly, export orientation is not a critical factor as the expert panel proposed. This implies foreign trade experts are focused on the product and the ability of the company to supply the product regardless of international network of the company. Glavas and Mathews (2014) demonstrated that previous international networking and business experience are not essential for the international business success of SMEs supporting this conclusion. Responsiveness of the website is not considered as a significant factor for website effectiveness. Responsiveness is more important for the websites of e-commerce (Lee, Kozar 2006) and hospitality (Akincilar, Dagdeviren 2014) which the users need interaction. Our results pertaining responsiveness is counter-intuitive which suggests trade experts perceive websites as a communication channel rather than a transaction platform. Attractiveness has the lowest global weight indicating foreign trade practitioners are less interested in the style.

Our approach and the results on the website ranking show that it is possible to use multicriteria decision-making methods in developing a model for assessing websites. The interdependence between the criteria and sub-criteria has been analysed by the experts' panel as a first step in the development of the model. It is determined that there is no significant interdependence between the criteria and sub-criteria. In other words, the impact of one criterion on the other is insignificant (i.e. the level of system quality has no considerable influence on information quality). In addition, it is decided that there is no interdependence between the levels. The outcome of the preliminary assessment of the problem showed that the AHP method is more suitable in the solution of the problem. The AHP hierarchy of our method in 
evaluating SME websites and discovering best alternative is illustrated in Figure 1. The figure depicts the levels of our decision-making process and the aspects related to each level hierarchically. The proposed model can enable SMEs measure and benchmark the effectiveness of their corporate websites. The implementation of the model can guide SMEs in exploring the areas of improvement in their websites, particularly in terms of export facilitation.

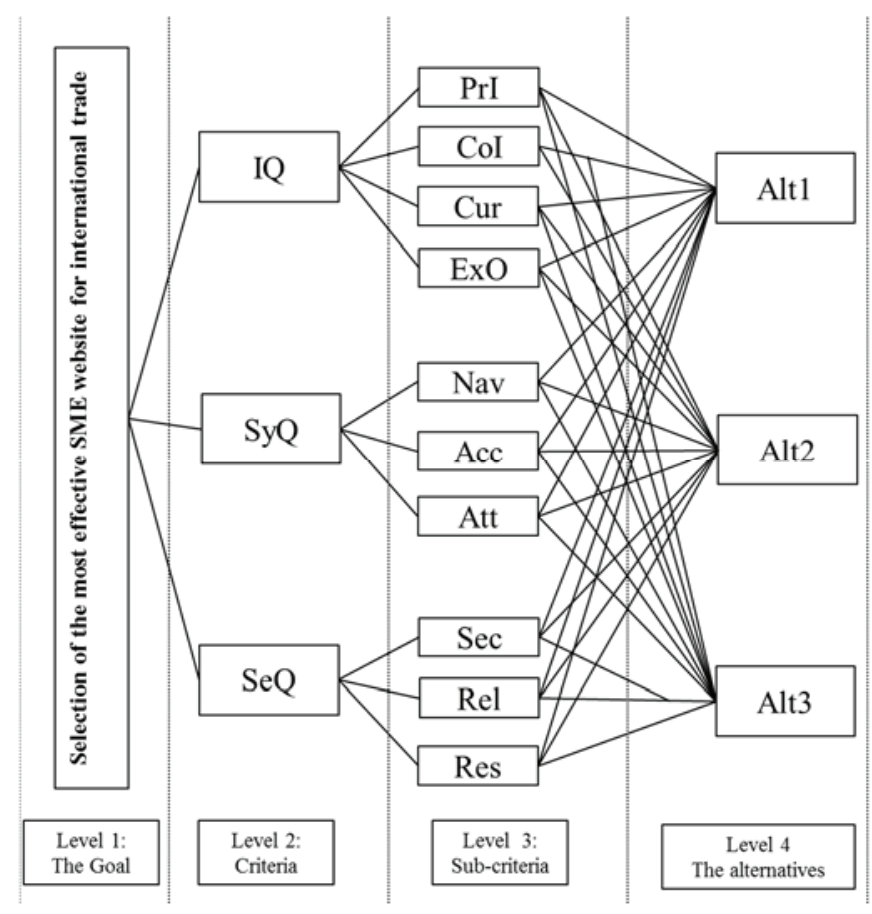

Figure 1. Hierarchy of the AHP model

The main objective of the study is discovering the factors that make a SME website good for international trade. The results of the study reveal the hierarchical importance of the factors which serve the SMEs in obtaining an efficient website in terms of their foreign trade. First of all, the SMEs need a website that provides current information for the trade partners. Then, including detailed product information is an important aspect of a successful website in terms of international trade. Navigability, reliability and accessibility are following important features of a good website for foreign trade. Security, company information, responsiveness, export orientation and attractiveness are also criteria that contribute having good websites for international trade respectively.

\section{Conclusions}

The websites of companies are open exhibitions that provide a fast and borderless channel of conveying information and gaining new customers. The aim of this research is to design a practical, robust, reliable, flexible and comprehensive model for assessing websites of SMEs 
from an international trade perspective. The literature has suggested many criteria affecting website effectiveness. We further investigated the website effectiveness of SMEs from the focus of international trade participants. The AHP method, which synthesizes decisions of multiple experts providing consistent and unbiased results, is employed. The criteria assigned for the issue of SME website evaluation acquired by literature review and experts' panel.

The criteria assessment and website ranking are performed by foreign trade experts. The results suggest that product information and currency are the most important criteria for the website of a SME involved in foreign trade. Navigability, reliability, and accessibility are the subsequent criteria. Surprisingly, export orientation hasn't been viewed as a critical factor by experts. However, this is an encouraging result for SMEs planning to enter foreign markets and become a global enterprise. Participants of international trade value the goods or services offered more than trade experience of the partners. Results also indicate that SME websites are viewed as a communication avenue rather than a transaction platform.

The proposed model shows that it is possible to measure the preference of websites based on certain criteria. The evaluation results can provide assistance for both designers and managers in developing policies for improving SME website effectiveness. Our results can contribute enhancing SME websites and increase their role in entering foreign markets and sustaining competitiveness.

The research was based on foreign trade expert assessments producing dependable results. However, this fosters a potential limitation as not all participants of international trade are experts and they may have different perceptions. Effects of the heterogeneity of audience can be dealt with by employing different-level expertise groups in future works. Another extension to this study would be utilizing integrating another MCDM tools to provide more precise results.

\section{References}

Akincilar, A.; Dagdeviren, M. 2014. A hybrid multi-criteria decision making model to evaluate hotel websites, International Journal of Hospitality Management 36: 263-271.

https://doi.org/10.1016/j.ijhm.2013.10.002

Akkaya, G.; Turanoglu, B.; Oztas, S. 2015. An integrated fuzzy AHP and fuzzy MOORA approach to the problem of industrial engineering sector choosing, Expert Systems with Applications 42(24): 9565-9573. https://doi.org/10.1016/j.eswa.2015.07.061

Akman, E. 2016. The facilitating role of visa policies on international trade and foreign direct investment, Turkish Studies 17(4): 712-732 . https://doi.org/10.1080/14683849.2016.1232589

Albayrak, E.; Erensal, Y. C. 2004. Using analytic hierarchy process (AHP) to improve human performance: an application of multiple criteria decision making problem, Journal of Intelligent Manufacturing 15(4): 491-503. https://doi.org/10.1023/B:JIMS.0000034112.00652.4c

Beckinsale, M.; Levy, M.; Powell, P. 2006. Exploring internet adoption drivers in SMEs, Electronic Markets 16(4): 361-370. https://doi.org/10.1080/10196780600999841

Bianchi, C.; Mathews, S. 2016. Internet marketing and export market growth in Chile, Journal of Business Research 69(2): 426-434. https://doi.org/10.1016/j.jbusres.2015.06.048

Bulicek, J.; Drdla, P. 2015. Quality of urban public transport websites according to extent of provided information, Transport 30(2): 202-216. https://doi.org/10.3846/16484142.2015.1048721 
Cebi, S. 2013. Determining importance degrees of website design parameters based on interactions and types of websites, Decision Support Systems 54(2): 1030-1043. https://doi.org/10.1016/j.dss.2012.10.036

Cheek, R.; Sale, M. L.; Schwarz, C. 2016. Creation of an instrument to measure website effectiveness using the Analytic Hierarchy Process (AHP), in I. Li (Ed.). The encyclopedia of e-commerce development, implementation, and management. IGI Global, 429-440.

Chen, S.; Li, R.; Tang, B. 2012. Group-buying website evaluation based on combination of TOPSIS, Entropy Weight and FAHP, Journal of Convergence Information Technology 7(7): 130-139. https://doi.org/10.4156/jcit.vol7.issue7.17

Cheng, C. H.; Yang, K. L.; Hwang, C. L. 1999. Evaluating attack helicopters by AHP based on linguistic variable weight, European Journal of Operational Research 116(2): 423-435. https://doi.org/10.1016/S0377-2217(98)00156-8

Choi, C. 2010. The effect of the internet on service trade, Economics Letters 109(2): 102-104. https://doi.org/10.1016/j.econlet.2010.08.005

Chou, W. C.; Cheng, Y. P. 2012. A hybrid fuzzy MCDM approach for evaluating website quality of professional accounting firms, Expert Systems with Applications 39(3): 2783-2793. https://doi.org/10.1016/j.eswa.2011.08.138

Contractor, F. J.; Hsu, C.-C.; Kundu, S. K. 2005. Explaining export performance: a comparative study of international new ventures in Indian and Taiwanese software industry, Management International Review 45: 83-110.

Dagdeviren, M.; Yuksel, İ. 2008. Developing a fuzzy analytic hierarchy process (AHP) model for behavior-based safety management, Information Science 178: 1717-1733. https://doi.org/10.1016/j.ins.2007.10.016

Dou, W.; Tan, C. M. 2002. Using corporate websites for export marketing, Journal of Advertising Research 42(5): 105-116. https://doi.org/10.2501/JAR-42-5-105-116

Ecer, F. 2014. A hybrid banking websites quality evaluation model using AHP and COPRAS-G: a Turkey case, Technological and Economic Development of Economy 20(4): 758-782. https://doi.org/10.3846/20294913.2014.915596

Fink, C.; Aaditya, M.; Ileana, C. N. 2005. Assessing the impact of communication costs on international trade, Journal of International Economics 67(2): 428-45. https://doi.org/10.1016/j.jinteco.2004.09.006

Fox, W. P. 2015. Introduction to multi-attribute decision making in business analytics, in Advanced business analytics. Springer International Publishing, 55-91.

Franco, C. A. 2014. On the analytic hierarchy process and decision support based on fuzzy-linguistic preference structures, Knowledge-Based Systems 70: 203-211. https://doi.org/10.1016/j.knosys.2014.06.028

Freund, C.; Weinhold, D. 2004. The Effect of the internet on international trade, Journal of International Economics 62: 171-89. https://doi.org/10.1016/S0022-1996(03)00059-X

Glavas, C.; Mathews, S. 2014. How international entrepreneurship characteristics influence Internet capabilities for the international business processes of the firm, International Business Review 23(1): 228-245. https://doi.org/10.1016/j.ibusrev.2013.04.001

Goedhuys, M.; Sleuwaegen, L. 2009. High-growth entrepreneurial firms in Africa: a quantile regression approach, Small Business Economics 34: 31-51 https://doi.org/10.1007/s11187-009-9193-7

Hajidimitriou, Y. A.; Azaria, A. C. 2009. Internet and export marketing: impact of internet use on export revenues of Greek SMEs, 35 $5^{\text {th }}$ EIBA Annual Conference on "Reshaping the Boundaries of the Firm in an Era of Global Interdependence", 13-15 December 2009, Valencia, Spain.

Ho, W. 2008. Integrated analytic hierarchy process and its applications - a literature review, European Journal of Operational Research 186(1): 211-228. https://doi.org/10.1016/j.ejor.2007.01.004 
Houghton, K. A.; Winklhofer, H. 2004. The effect of website and e-commerce adoption on the relationship between SMEs and their export intermediaries, International Small Business Journal 22(4): 369-388. https://doi.org/10.1177/0266242604044305

Kang, D.; Jang, W.; Park, Y. 2016. Evaluation of e-commerce websites using fuzzy hierarchical TOPSIS based on ES-QUAL, Applied Soft Computing 42: 53-65. https://doi.org/10.1016/j.asoc.2016.01.017

Karmokar, S.; Singh, H. 2012. Improving the website design process for SMEs: a design science perspective, in International Conference on Information Resources Management (Conf-IRM), 21-23 May 2012, Vienna, Austria, Paper 26.

Katsikeas, C. S.; Deng, S. L.; Wortzel, L. H. 1997. Perceived export success factors of small and mediumsized Canadian firms, Journal of International Marketing 5: 53-72.

Kaya, T.; Kahraman, C. 2011. A fuzzy approach to e-banking website quality assessment based on an integrated AHP-ELECTRE method, Technological and Economic Development of Economy 17(2): 313-334. https://doi.org/10.3846/20294913.2011.583727

Kincl, T.; Štrach, P. 2012. Measuring website quality: asymmetric effect of user satisfaction, Behaviour \& Information Technology 31(7): 647-657. https://doi.org/10.1080/0144929X.2010.526150

Lee, Y.; Kozar, K. A. 2006. Investigating the effect of website quality on e-business success: an analytic hierarchy process (AHP) approach, Decision Support Systems 42(3): 1383-1401. https://doi.org/10.1016/j.dss.2005.11.005

Li, J. J.; Liu, L. W. 2015. An MCDM model based on KL-AHP and TOPSIS and its application to weapon system evaluation, in Proceedings of the $5^{\text {th }}$ International Asia Conference on Industrial Engineering and Management Innovation (IEMI2014), Atlantis Press, Paris, 257-262. https://doi.org/10.2991/978-94-6239-100-0_48

Li, M. 2015. A study on comprehensive evaluation of C2C e-commerce website competitiveness, in Proceedings of the 2015 International Conference on Education Technology a nd Economic Management, 14-15 March 2015, Beijing, PRC, 600-603.

Lileeva, A.; Trefler, D. 2010. Improved access to foreign markets raises plant-level productivity... for some plants, The Quarterly Journal of Economics 125(3): 1051-1099. https://doi.org/10.1162/qjec.2010.125.3.1051

Lin, H. F. 2010. An application of fuzzy AHP for evaluating course website quality, Computers \& Education 54(4): 877-888. https://doi.org/10.1016/j.compedu.2009.09.017

Madill, J.; Neilson, L. C. 2010. Web site utilization in SME business strategy: the case of Canadian wine SMEs, Journal of Small Business \& Entrepreneurship 23(4): 489-507. https://doi.org/10.1080/08276331.2010.10593497

Mardani, A.; Jusoh, A.; Zavadskas, E. K.; Khalifah, Z.; Nor, K. M. 2015. Application of multiple-criteria decision-making techniques and approaches to evaluating of service quality: a systematic review of the literature, Journal of Business Economics and Management 16(5): 1034-1068. https://doi.org/10.3846/16111699.2015.1095233

Masudin, I.; Saputro, T. E. 2016. Evaluation of B2C website based on the usability factors by using fuzzy AHP \& hierarchical fuzzy TOPSIS, in IOP Conference Series: Materials Science and Engineering 114(1): 012091. IOP Publishing. https://doi.org/10.1088/1757-899X/114/1/012091

Mathews, S.; Healy, M.; Wickramasekera, R. 2012. The Internetalisation of information, knowledge, and interaction components of the firm's internationalisation process, Journal of Marketing Management 28(5-6): 733-754. https://doi.org/10.1080/0267257X.2011.560887

Meng, L.; Wu, J. 2014. Evaluation of the trading website for agricultural products in China, Asian Agricultural Research 6(09): 14-22.

Moini, H.; Tesar, G. 2005. The internet and the internationalization of smaller manufacturing enterprises, Journal of Global Marketing 18(3/4): 79-94. https://doi.org/10.1300/J042v18n03_04 
Mosadeghi, R.; Warnken, J.; Tomlinson, R.; Mirfenderesk, H. 2015. Comparison of Fuzzy-AHP and AHP in a spatial multi-criteria decision making model for urban land-use planning, Computers, Environment and Urban Systems 49: 54-65. https://doi.org/10.1016/j.compenvurbsys.2014.10.001

Saaty, T. L.; Ozdemir, M. S.; Shang, J. S. 2015. The rationality of punishment-measuring the severity of crimes: an AHP-based orders-of-magnitude approach, International Journal of Information Technology \& Decision Making 14(01): 5-16.

Saaty, T. L. 1980. The analytic hierarchy process. New York: McGraw-Hill.

Samiee, S. 1998. Exporting and the internet: a conceptual perspective, International Marketing Review 15(5): 413-426. https://doi.org/10.1108/02651339810236452

Sanders, J.; Galloway, L. 2013. Rural small firms' website quality in transition and market economies, Journal of Small Business and Enterprise Development 20(4): 788-806. https://doi.org/10.1108/JSBED-01-2012-0009

Sinkovics, R. R.; Penz, E. 2006. Empowerment of SME websites - development of a web-empowerment scale and preliminary evidence, Journal of International Entrepreneurship 3(4): 303-315. https://doi.org/10.1007/s10843-006-7858-8

Stockdale, R.; Lin, C.; Stoney, S. 2005. The effectiveness of SME websites in a buiness to business context, in Proceedings of IADIS International Conference e-Commerce, Portugal, 259-266.

Ting, P. H.; Wang, S. T.; Bau, D. Y.; Chiang, M. L. 2013. Website evaluation of the top 100 hotels using advanced content analysis and eMICA model, Cornell Hospitality Quarterly 54(3): 284-293. https://doi.org/10.1177/1938965512471892

Tyagi, S. 2016. An improved fuzzy-AHP (IFAHP) approach to compare SECI modes, International Journal of Production Research 54(15): 4520-4536. https://doi.org/10.1080/00207543.2015.1067378

Veisi, H.; Liaghati, H.; Alipour, A. 2016. Developing an ethics-based approach to indicators of sustainable agriculture using analytic hierarchy process (AHP), Ecological Indicators 60: 644-654.

Waite, K.; Harrison, T.; Hunter, G. 2011. Exploring bank website expectations across two task scenarios, Journal of Financial Services Marketing 16(1): 76-85. https://doi.org/10.1057/fsm.2011.6

Wang, M. C. H.; Khalil, S.; Blankson, C.; Cheng, J. M. S. 2011. The influence of the provision of online channel functions on exporting channel performance: the moderating effect of international experience, Journal of Global Marketing 24(2): 125-135. https://doi.org/10.1080/08911762.2011.558811

Xiaolan, Z.; Hong, X.; Huiping, Y. 2013. Determination of the weight values of assessment indexes of website based on AHP-take the website of university library as an example, in 2013 Fifth International Conference on Computational and Information Sciences (ICCIS), IEEE, 21-23 June 2013, 652-655. https://doi.org/10.1109/ICCIS.2013.177

Yu, X.; Guo, S.; Guo, J.; Huang, X. 2011. Rank B2C e-commerce websites in e-alliance based on AHP and fuzzy TOPSIS, Expert Systems with Applications 38(4): 3550-3557. https://doi.org/10.1016/j.eswa.2010.08.143

Zavadskas, E. K.; Turskis, Z. 2011. Multiple criteria decision making (MCDM) methods in economics: an overview, Technological and Economic Development of Economy 17(2): 397-427. https://doi.org/10.3846/20294913.2011.593291 